\title{
SHORT CONSIDERATIONS REGARDING THE MAGISTRATES'LIABILITY IN THE CONTEXT OF THE NEW LEGAL PROVISIONS ON THE REFORM IN JUSTICE
}

\section{MANOLIU}

\section{Constantin MANOLIU}

PhD Student at "Alexandru Ioan Cuza" Police Academy from Bucharest, Romania - Doctoral School of Law

Domicile: Oradea, C. Tănase street, no. 2/A, ap. 3, Bihor county

E-mail: costi_manoliu@yahoo.com

\section{ABSTRACT}

The present study analyzes the magistrates' responsibility, in the light of the old and the new legal regulations, the exercise of the right to recourse action of the state against magistrates in case of judicial errors, and the conditions that must be be met in order to promote this action.

The author identifies possible vulnerabilities of the new regulations on the magistrates' civil liability, vulnerabilities that may affect the magistrates 'independence in the exercise of their job duties.

The study is focused on the new amendments of the Law no. 303/2004 on the status of magistrates, brought by Law no. 242/2018, as regards the civil liability of magistrates, includes issues related to the guarantees regarding the enforcement of the principles of independence and impartiality of magistrates, guarantees aimed at maintaining a balance between the magistrates' responsibility and their independence.

KEYWORDS: magistrates 'liability, recourse action, judicial error, bad faith, serious negligence.

\section{INTRODUCTION}

In the exercise of their job duties, judges and prosecutors are not avoided by possible judicial errors that have the consequence of harming a person's interests. In this context, in a legal state, there must exist the possibility of magistrates' liability for the judicial errors committed and, consequently, of repairing the damages caused to injured persons as a result of the magistrate's decision or behavior.

As regards the magistrates 'liability, both the Constitution of Romania and the Law on the statute of judges and prosecutors provide that magistrates can be held accountable, through the special law being regulated three forms of liability: civil, disciplinary and criminal under the law ${ }^{1}$.

\footnotetext{
${ }^{1}$ Article 94 of Law no. 303/2004 published in the Official Gazette of Romania, Part I, no. 576 from 29 June 2004, as amended and republished on the basis of Art. XII of Title XVII of Law no. 247/2005 regarding the reform in the field of property and justice, as well as some related measures, published in the Official Gazette of Romania, Part I, no. 653 of 22 July 2005, giving the texts a new numbering; https://www.juridice.ro/549626/raspunderea-civila-a-magistratilor-in-contextul-noilor-propuneri-legislative.html -06.01.2019
} 


\section{Constantin Manoliu}

Criminal liability is that form of legal liability arising out of committing a criminal offense and represents the consequence of disregarding the legal criminal provisions and involves the obligation of a person to be liable before the criminal investigation authorities and then before the court for the offense provided by the criminal law, that he has committed, the obligation to bear the criminal coercive measures provided by the law for committing the offense and the obligation to execute the penalty imposed.

The disciplinary liability is that form of the legal liability arising from the violation of the rules of law that represent a disciplinary deviation, rules designed to determine the magistrate to exercise the powers granted to him with responsibility.

The magistrate may also be disciplinarily liable for certain actions or inactions that are not related to the exercise of his job duties, but which affect the justice prestige ${ }^{2}$.

Civil liability of magistrates is a special one, derogating from the common law. Such liability is grounded on the notion of the state guarantee, as representative of the public authority, for damages caused to injured parties as a result of committing certain judicial errors during judicial proceedings.

The civil liability of magistrates has a subsidiary nature and is engaged when the state has covered the damage caused by the judicial error. ${ }^{3}$

Judicial errors can be caused not only by the culpable acts of the judge or the prosecutor, but also by other circumstances independent of the judge or prosecutor who has given the prejudicial solution by example: poor legislation and contrary to the European Convention on Human Rights, such as the one in the field of properties refund, the one regarding the unanimity in actions in return, etc.

Furthermore, one shall analyze the civil liability of magistrates in the context of the new legislative amendments, the disciplinary and criminal liability being evoked only in places where they are relevant to the engagement of the civil liability.

\section{PRELIMINARY CONSIDERATIONS}

The Constitution of Romania states in art. 52 par. (3) the principle of patrimonial liability of the State for damages caused by prosecutors and judges through the judicial errors made by them in the case files they have settled ${ }^{4}$.

The constituent legislator does not specify the nature of the case files where judicial errors have been made, thus they can include both criminal and civil matters.

The constitutional text is developed in Law no. 303/2004 on the status of judges and prosecutors in Title IV with reference to "Liability of judges and prosecutors", art. 94-101, legal text that will be further analyzed from the perspective of the current regulations.

Thus, the new amendments to the Law no. 303/2004 on the status of judges and prosecutors by Law no. 242 from 2018 have created a new framework for carrying out the judicial activity by magistrates, essential amendments were made to the status of the judge and the prosecutor, as well as changes in guaranteeing their independence. Also, new regulations have been

\footnotetext{
${ }^{2}$ See art 99 of Law no.303/2004, published in the Official Gazzette number 576 from 29 June 2004

${ }^{3}$ See also the old regulation, art 94 and art 96 para 1 and 2 of Law no.303/2004

${ }^{4}$ Article 52 paragraph 3 of the Constitution of Romania, republished, published in the Official Gazette no. 767 of October 31, 2003, states that "the State shall be liable for the damages caused by judicial errors. State liability is established under the law and does not remove the liability of magistrates who have performed their duties in bad faith or serious negligence".
} 
introduced regarding the magistrates' liability and the conditions under which this liability can be engaged ${ }^{5}$.

In its jurisprudence, the Constitutional Court held that in the process of performing the act of justice, the judge magistrate is not holder of own subjective rights, which abusive exercise may lead to the violation of the rights of other persons, the judge belongs to the judiciary authority, he rules decisions not only in the name of the law, but also in that of the state he represents, state that rules the law to which he is subjected. From this perspective, it is natural that, in the event of commiting a judicial error, the person concerned should turn directly against the State and not against the Judge, the latter being merely a representative of the first ${ }^{6}$.

The new legislative amendments have regulated the separation of the two carreers, of judges 'and prosecutors' magistrates, the prosecutors magistrates as exponents of the Public Ministry manage the criminal prosecution files, and have a specific responsibility for these activities $^{7}$.

\section{GENERAL PRINCIPLES}

The general principles emerging from the new regulation of the statute of magistrates can be summarized as it follows:

The principle of the magistrates'independence in the exercise of their office;

Principle of state liability for the judicial errors committed by magistrates; The action of the injured party against the State as guarantor of the damage repair;

The principle of repairing the damage caused by magistrates in the exercise of their position in bad faith or serious negligence; State's recourse action in the event of the exercise of the powers.

The balance between the magistrate's independence and his liability under the law in relation to the exercise in good faith of their activity.

\subsection{Principle of the magistrates' independence}

The independence of the magistrate is the premise of the state of law and the fundamental guarantee of a fair judgment. This implies that no one can intervene in the judgments or the thinking manner of the judge or prosecutor ${ }^{8}$.

\subsection{Principle of the judges'independence}

The independence of judges is regulated by art. 124 par. 3 of the Constitution of Romania, which provides that the judges are independent and are subjected only to the law. Independence of judges is guaranteed by their statute granted by Law no. 303/2004 on the statute of judges and prosecutors, which regulates the appointment and promotion of magistrates.

\footnotetext{
${ }^{5}$ Law no. 242/2018 from 12 October 2018 for amending and completing Law no. 303/2004 on the status of judges and prosecutors published in: Official Gazette no. 868 from 15 October 2018.

${ }^{6}$ Paragraph 31 of the Constitutional Court Decision no. 263 from 23 April 2015 on the exception of unconstitutionality of the provisions of art. 96 of the Law no. 303/2004 on the status of judges and prosecutors published in the Official Gazette no. 415 from 11 June 2015.

${ }^{7}$ Art. 1 of the Law no.242 / 2018 provides that "(2) The judge's career is separated from the career of the prosecutor, the judges being unable to interfere in the career of prosecutors and the prosecutors in the judges'carreer."

${ }^{8}$ https://www.juridice.ro/38387/independenta-si-impartialitatea-magistratului-legislatie-doctrinajurisprudenta.html 17.10.2018.
} 


\section{Constantin Manoliu}

Another guarantee given to judges magistrates which ensure their independence is given by their security of tenure. This implies that any advancement or transfer can only be done with the consent of the judges. The security of tenure is regulated as principle in the Constitution of Romania ${ }^{9}$.

Through the new regulation, referring to the independence of the judge, the legislator emphasized their full freedom in settling the cases brought to justice with observing the equality of arms and the procedural rights of the parties ${ }^{10}$.

\subsection{Principle of prosecutors' independence}

A judiciary system based on observing the principles of the state of law needs - in addition to the guarantees given to judges - strong, independent and impartial prosecutors willing to start an investigation and to prosecute suspicious facts and persons, regardless of the status or level of influence of these persons in the society. The authority initiating the law enforcement in the criminal justice on behalf of the society and of the public interest should enjoy a type of independence, similar to that of judges ${ }^{11}$.

In the context of the constitutional rules and of the new regulations, respectively of the provisions listed by Article 132 of the Constitution of Romania and by Article 3 para. 1 of the Law no. 304/2004 on judicial organization as amended by Law no. 242/2018 "Prosecutors carry out their activity according to the principles of legality, impartiality and hierarchical control, under the authority of the Minister of Justice."

According to this principle, the Public Ministry is conceived as a pyramidal system where the prosecutors in each prosecutor's office are subordinated to the head of that prosecutor's office and the head of a prosecutor's office is subordinated to the head of the hierarchically superior prosecutor's office $^{12}$.

Prosecutors are independent in ruling solutions, under the conditions provided by art. 64 of the Law no. 304/2004 on judicial organization, republished, as amended and completed. In the new regulation ${ }^{13}$, the solutions taken by the prosecutor can be invalidated in a reasoned manner by the hierarchically superior prosecutor, when they are considered as illegal or groundless, towards the old regulation when the prosecutor's solutions could have been invalidated only due to illegality reasons.

This new legislative approach can be perceived as an interference with the independence of the prosecutor in the exercise of his duties in the current context, since, in the absence of a

\footnotetext{
${ }^{9}$ Art. 125 para. (1) of the Constitution of Romania provides that "Judges appointed by the President of Romania are irremovable, under the law"

10 Art. 2 of the Law no. 242/2018, which states that "Judges are independent and are subject only to the law. Judges must be impartial, having full freedom in settling cases brought to justice, in accordance with the law and impartially, with due respect for arms equality and for the procedural rights of the parties. Judges must take decisions without any restrictions, influences, pressures, threats or interventions, either direct or indirect, from any authority, or even from judicial authorities. Decisions ruled in appeal do not fall under these restrictions. The purpose of the judges' independence also includes ensuring that every person has the fundamental right to have his case heard on an equitable basis, based solely on law enforcement."

11 RECJ Report 2014-2016 published on the website https://www.csm1909.ro/ViewFile.ashx?guid=1c222af97731-45f9-b6a3-88b6630c7e9c|InfoCSM -17.10.2018.

${ }^{12}$ https://www.juridice.ro/38387/independenta-si-impartialitatea-magistratului-legislatie-doctrinajurisprudenta.html 17.10.2018.

${ }_{13}$ Art. 64 paragraph 3 of Law no.304 / 2004 as amended by Law no. 207/2018.
} 
clarification in law, of the term "groundless", increases the risk of interference in the individual case files of the prosecutors ${ }^{14}$.

A guarantee of the prosecutor' $s$ independence is also the fact that the prosecutors appointed by the President of Romania benefit from stability ${ }^{15}$.

\section{MAGISTRATES' LIABILITY: FRAMEWORK AND REGULATION - INTERNAL LEGISLATION}

As stated above, the Constitution of Romania, by art. 52 establishes the patrimonial responsibility of the state for judicial errors. This liability is governed by law and does not remove the liability of magistrates who have performed their duties in bad faith or serious negligence.

According to the provisions of art. 94 of Law 303/2004, judges and prosecutors are liable civilly, disciplinarily and criminally according to the law.

From the above mentioned legal text result three types of magistrates'liability generated by the exercise of their specific position, namely: civil liability, disciplinary liability and criminal liability.

With regard to the criminal or disciplinary liability, any person concerned has the complete freedom to file an action against the judge / prosecutor who can take either the form of a criminal complaint or the form of a referral addressed to the Judicial Inspection within the Superior Council of Magistracy, under art. 45 par. (2) of the Law no. 317/2004.

In criminal matter, the right of the damaged party to the repair of damages caused by judicial errors committed in criminal proceedings is currently governed by Art. 538 par. (1) and (2) of the Criminal Procedure Code. At the same time, art. 539 par. (1) of the Criminal Procedure Code provides that is entitled to the repair of the damage also the person who was unlawfully deprived of freedom during the criminal proceedings" 16 .

In disciplinary matter, the new regulation has broadened the scope of disciplinary deviations, among which we mention the failure to draft or sign the judgments or the judicial documents of the prosecutor, due to attributable reasons, within the deadlines provided by law. The system of sanctions for commiting certain disciplinary deviations has also been tightened, including the sanction of professional downgrading ${ }^{17}$.

3.1. Principle of the state liability for judicial errors committed by magistrates; the action of the damaged party against the State as guarantor for the damage repair;

Through the new regulation of magistrates' liability the legislator set out the conditions under which the state is responsible for judicial errors, defined the notion of judicial error, the notion of bad faith and of serious negligence, as well as the conditions for exercising the recourse action against magistrates ${ }^{18}$.

\footnotetext{
${ }^{14}$ Preliminary Opinion no. 924/2018 of the European Commission for Democracy through Law (Venice Commission)

${ }^{15}$ Article 4 of Law No 242/2018 amending Law 303/2004 on the status of magistrates.

${ }^{16}$ Section 208 of the Constitutional Court Decision no. 45/2018.

${ }^{17}$ Articles 99 and 100 of Law no. 303/2004 amended by Law no.242 / 2018.

${ }^{18}$ Art. 151 of Law no. 242/2018 amending Law no. 303/2004 provides that "(3) There is a legal error when: a) during a trial there was ruled to carry out procedural acts with the obvious violation of the substantive and procedural legal provisions, which seriously violated the rights, freedoms and legitimate interests, causing a damage that could not be remedied by an ordinary or extraordinary remedy; (b) a final judgment which is obviously contrary to the law or to the factual situation resulting from the evidence managed, which seriously
} 


\section{Constantin Manoliu}

In the new vision of the law, the civil liability of the state for judicial error is no longer linked and is no longer prior conditioned by the engagement of the criminal or disciplinary liability of the magistrate through a final judgment, as previously regulated, but strictly by the idea of judicial error.

From the wording of the new normative text results that the state will compensate the damaged persons if a judicial error has occurred, irrespective of the conduct of the magistrate concerned; in practice, the civil liability of the state is removed from the sphere of criminal / disciplinary liability of the judge / prosecutor ${ }^{19}$.

As such, from the provisions of Art. 96 par. 3 of the Law no. 303/2004 result that, in the event of a judicial error, the damaged party may file an action against the State, represented by the Ministry of Public Finances, for the damage repair, action which falls under the jurisdiction of the county court in which jurisdiction the plaintiff is domiciled.

This new regulation, even if it fully satisfies the alleged victim of a judicial error, has unimaginable consequences in the current legal reality. Thus, it is known that one of the parties of the trial loses, and the other is satisfied with the decision taken by the magistrate.

The new regulation also opens the possibility for the party who lost the trial to invoke an alleged judicial error committed by the magistrate in the settlement of his case and to file an action against the state under Art. 96 par. 5 of the Law no. 303/2004, for the recovery of the presumed damage, which, in the author's opinion, constitutes an appeal to appeal.

In the absence of some concrete guarantees, such as the decrease of the state's right to dispose in the proceedings filed by the damaged person, namely the limitation of the State's possibility to meet the plantiff's claims, and the imposition of the court's obligation to effectively verify the existence of the judicial error, since, after the final judgment by which the error was found and the indemnities have been settled in favor of the plaintiff, the State is obliged to file the recourse action against the magistrate who committed the error.

Another negative aspect of this regulation is the fact the magistrate who ruled the solution which determined the alleged judicial error, although is not a party in the action filed by the damaged person, he must follow the existence of these actions and to intervene in the trial in order to prevent a possible recourse actio $^{20}$.

Or, as provided by Art. 53 of Opinion 3 of the Consultative Council of European Judges CCJE, "the judge does not have to work under the threat of a pecuniary punishment, even less of one with imprisonment, which presence may, even subconsciously, affect his judgment" 21 .

3.2. Principle of repairing the damage caused by magistrates in the exercise of their office in bad faith or serious negligence; Recourse action of the state against magistrates.

In accordance with the provisions of art. 96 paragraph 7-9 of the Law no. 303/2004 amended, (7) within two months of the notification of the final decision ruled in the action provided by para. (6), the Ministry of Public Finances shall notify the Judicial Inspection in order to verify whether the judicial error was caused by the judge or prosecutor as a result of the exercise of their position in bad faith or serious negligence, according to the procedure provided by Art. $74 \wedge 1$ of the Law no. 317/2004, republished, as subsequently amended.

affects the legitimate rights, freedoms and interests of the person, which could not be remedied by a ordinary or extraordinary appeal.(...)".

${ }^{19}$ Section 215 of the Constitutional Court Decision no. 45/2018.

${ }^{20}$ Section 221 of the Constitutional Court Decision no. 45/2018.

${ }^{21} \mathrm{https}: / /$ www.csm1909.ro/303/3937/Consiliul-Consultativ-al-Judec\%C4\%83torilor-Europeni-(CCJE). 
(8) The State, through the Ministry of Public Finances, shall file recourse action against the judge or the prosecutor if, following the consultative report of the Judicial Inspection provided by par. (7) and its own assessment, considers that the judicial error was caused as a result of the exercise by the judge or prosecutor of their office in bad faith or serious negligence. (....)".

As it can be seen, through the new regulation, the State, through the Ministry of Public Finances, is obliged to exercise the recourse action towards the previous regulation when the recourse action was optional.

The above mentioned legal text provides the following conditions for exercising the recourse action against the magistrate:

1. The existence of a final court judgment ruled in the action provided by paragraph 3 of Art. 96 of the Law no. 303/2004 amended, respectively the action of the damaged party filed against the State.

2. the existence of bad faith or serious negligence in committing the judicial error, ascertained by the Judicial Inspection, or considered by the Ministry of Public Finances following its own assessment;

3. filing the recourse action should be made within 6 months from the date of notifying the report of the Judicial Inspection.

As regards its own assessment that must be made by the Ministry of Public Finances regarding the existence of bad faith or serious negligence in committing the judicial error, the Constitutional Court has held that, through this assessment, it is avoided the mechanical filing of recourse actions whenever it was found a judicial error even in the absence of bad faith or serious negligence of the judge / prosecutor $^{22}$.

Regarding the appeal that may be filed against the judgment ruled in the state's action filed against the magistrate, the new regulation provided the second appeal to the appropriate section of the High Court of Cassation and Justice ${ }^{23}$.

The new regulation establishes the obligation for the Superior Council of Magistracy to lay down the conditions, deadlines and procedures for the compulsory professional insurance of judges and prosecutors within 6 months from the entry into force of the law ${ }^{24}$.

The legislator provided that the insurance would be fully covered by the judge or prosecutor and its absence could not delay, diminish or remove the civil liability of the judge or prosecutor for the judicial error caused by the exercise of the office in bad faith or serious negligence.

I consider that the professional risk insurance should take the form of a collective insurance concluded by the Superior Council of Magistracy as a guarantor of the independence of the magistrates, insurance borne by the state in relation to the number of cases completed through the number of final court decisions admitted, through which was admitted the recourse action for a period of one year, or the average for a period of 5 years, given that the magistrates are exponents of the judiciary power and do not act in their own name.

\footnotetext{
${ }^{22}$ Decision of the Constitutional Court no. 263 from 23 April 2015.

${ }^{23}$ Art. 96 para 10 of Law no.303/2018 amended by Law no..242/2018.

${ }^{24}$ Art. 96 para 11 of Law no.303/2018 amended by Law no..242/2018.
} 


\section{Constantin Manoliu}

Moreover, the obligation of the magistrate to conclude and pay a professional risk insurance is likely to lead to an indirect decrease in his salary incomes, without any grounded reason, and without knowing the limit of his incomes, which is in contradiction with the provisions of Art. 74 par. 2 of Law 303/2004, legal text providing that "(2) The salary rights of judges and prosecutors can be decreased or suspended only in the cases provided by the present law".

\section{CONCLUSIONS}

Legislative changes regulating the magistrates'liability, civil, disciplinary and criminal, and cases where this liability operates, and the procedure to be followed, do not provide all the procedural guarantees in order to avoid affecting the independence of magistrates.

In this respect, we point out that the action filed against the state by the person damaged through a judicial error is no longer conditional on the existence of a final court judgment establishing the judicial error and the possibility that the State through the Ministry of Public Finances to be able to satisfy the plaintiff's claims and thus create the premise of the recourse action without a court to analyze in fact the existence of the judicial error, since in the recourse action is verified only the existence of bad faith or serious negligence of the magistrate in committing the judicial error, and not its existence.

As such, in this situation it is necessary to provide certain procedural guarantees, such as the limitation of the principle of availability as regards the possibility for the State to satisfy the claims of the plaintiff, victim of a possible judicial error in the action filed by him against the State. At the same time, I consider that the professional risk insurance should have taken the form of a collective insurance concluded by the Superior Council of Magistracy as a guarantor of the independence of the magistrates, with the arguments set out above.

\section{BIBLIOGRAPHY}

1. The Constitution of Romania republished, published in the Official Gazette no. 767 from 31 October 2003;

2. Law no. 303/2004 published in the Official Gazette of Romania, Part I, no. 576 from 29 June 2004;

3. Law no. 242/2018 from 12 October 2018 for amending and completing the Law no. $303 / 2004$ on the status of judges and prosecutors published in the Official Gazette no. 868 from 15 October 2018;

4. Decision of the Constitutional Court no. 263 from 23 April 2015 on the exception of unconstitutionality of the provisions of art. 96 of the Law no. 303/2004 on the status of judges and prosecutors published in the Official Gazette no. 415 from 11 June 2015;

5. Decision of the Constitutional Court no.45 / 2018 published in the Official Gazette no. 199 from 5 March 2018;

6. RECJ Report 2014-2016 https://www.csm1909.ro/ViewFile.ashx?guid=1c222af97731-45f9-b6a3-88b6630c7e9c|InfoCSM -17.10.2018;

7. Preliminary opinion no. 924/2018 of the European Commission for Democracy through Law (Venice Commission);

8. Opinion 3 of the CCJE Consultative Council of European Judges

9.https://www.juridice.ro/549626/raspunderea-civila-a-magistratilor-in-contextulnoilor-propuneri-legislative.html; 
10.https://www.juridice.ro/38387/independenta-si-impartialitatea-magistratuluilegislatie-doctrina-jurisprudenta.html 17.10.2018;

11. https://www.csm1909.ro/303/3937/Consiliul-Consultativ-al-Judec\%C4\%83torilorEuropeni-(CCJE) 